\title{
Cutaneous Metastasis of Neuroendocrine Carcinoma with Unknown Primary Site: Case Report and Review of the Literature
}

\author{
Gustavo Moreira Amorim $^{a} \quad$ Danielle Quintella $^{b} \quad$ Tullia Cuzzi $^{b}$ \\ Rosangela Rodrigues $^{a} \quad$ Marcia Ramos-e-Silva ${ }^{a}$ \\ ${ }^{a}$ Sector of Dermatology and Post-Graduation Course and ${ }^{b}$ Sector of Pathology, \\ University Hospital and School of Medicine, Federal University of Rio de Janeiro, \\ Rio de Janeiro, Brazil
}

\section{Key Words}

Neuroendocrine carcinoma $\cdot$ Neuroendocrine tumor $\cdot$ Metastasis $\cdot$ Skin metastasis

\begin{abstract}
We report a new case of neuroendocrine carcinoma for which it was not possible to find the primary site until now. The recent medical literature about skin metastasis of neuroendocrine carcinoma (neuroendocrine tumor) is discussed.

\section{Introduction}

Neuroendocrine tumors (NETs) constitute a heterogeneous group of neoplasia, gathered together because of their common features: tumors capable of secreting hormones, neurotransmitters, neuromodulators and neuropeptides. Neuroendocrine cells, supposedly precursors of this group of neoplasia, are found in all solid organs, skin and mucosae; therefore, NETs may originate in several locations [1-3].

Their incidence varies in different studies. Data from the US and Europe indicate an approximate incidence rate of 1-2 new cases/100,000 inhabitants per year. This represents about $0.5 \%$ of all malignancies. Some articles indicate that, although rare, NETs are presenting a discreet and progressive rise in their incidence [4]. 
The gastrointestinal tract is the most common primary site (62\%), where appendix $(27 \%)$ and the small intestine (15\%) are the most prevailing, followed by the lungs (23\%). It is relevant to highlight that up to $12 \%$ of the patients present metastases from an unknown primary site [4].

Within the spectrum of NETs, on the one side, well-differentiated NETs can be found (formerly called carcinoid tumors), usually with a painless clinical course, besides being curable by simple resection when viable. On the other side of the spectrum, there are poorly differentiated neuroendocrine carcinomas (NECs), of a more aggressive clinical course, producing metastases with greater frequency and, usually, requiring isolated or adjuvant chemotherapy [1,2]. Cutaneous manifestations from NETs are not uncommon, especially those exhibiting carcinoid syndrome. Flushing is the most common manifestation, present in all secretory tumors. Cutaneous metastases, however, are rare [3, 5].

We present the case of a patient with a diagnosis of NEC of undetermined primary site, diagnosed with lymph node metastasis and cutaneous lesions.

\section{Case Report}

A 65-year-old man with arterial hypertension was diagnosed 2 years before with NEC based on histopathological examination of a swollen lymph node in the right inguinal region. The patient was scanned with CT and scintigraphy; however, the site of the neoplasia was not identified. Nevertheless, 6 months ago, chemotherapy treatment was initiated with a combined scheme of carboplatin and etoposide.

Three months ago the patient noted nodular lesions visible on the right lower limb with progressive growth that led to the request of a consultation by a dermatologic peer.

At clinical examination, the lesions were more palpable than visible. There was no overlying erythema. They were restricted to the right thigh, in a linear trajectory, and the right buttock (fig. 1, fig. 2, fig. 3). The lesions were painless at touch, had a hardened consistency, measured up to $1.5 \mathrm{~cm}$ and were not adhered to deeper planes.

An excisional biopsy of one of the skin lesions was performed. Histopathological examination showed a nodule occupying the medium/deep reticular dermis and hypodermis, with expansive growth, comprising monomorphic cells with poorly defined cytoplasmic borders, round nucleus, and fine granular chromatin, delimited by delicate septa of connective tissue (fig. 4, fig. 5). Numerous figures of mitoses were noted. Immunohistochemistry showed focal positivity in paranuclear dot for CK20 (fig. 6), positivity for chromogranin (fig. 7) and synaptophysin and a cell proliferation index evaluated by Ki67 of about $60 \%$ (fig. 8). These findings were interpreted as compatible with cutaneous NEC metastasis.

The case was considered by the clinical oncologist as loss of response to treatment and progression of disease. Therefore, a chemotherapy rescue scheme was initiated with irinotecan. The patient is being followed up by both specialties.

\section{Discussion}

Carcinomas with unknown primary site represent about $2.3-4.2 \%$ of all malignant neoplasia cases (being seventh or eighth in frequency, depending on the casuistry). They seem to affect men more frequently, with onset in the fifth or sixth decade of life, being the fourth cause of death in both genders. Of these, $50 \%$ are at least moderately differentiated adeno- 
Amorim et al.: Cutaneous Metastasis of Neuroendocrine Carcinoma with Unknown Primary Site: Case Report and Review of the Literature

carcinomas. Up to $30 \%$ are poorly differentiated, and the NETs of unknown primary site are included in this group [6].

The detection of the primary site in metastatic NET is a challenge. The approach includes endoscopy and imaging (tomography and scintigraphy). Recently, evidences indicate benefits by using endoscopic ultrasound and PET CT [7].

As a group, NETs produce metastases in 30\% of cases, and among these a greater portion is attributed to NEC. The metastatic disease signals a worse prognosis. Other worse prognostic factors identified at histopathological examination are vascular and lymphatic invasion, a high grade of cell atypia, an increased nucleus/cytoplasm ratio, the presence and extension of necrosis, besides an increased mitotic index $[2,8]$. The cell proliferation index analyzed by immunohistochemistry (Ki67) contributes to this assessment. Poorly differentiated NEC, with a Ki67 $>20 \%$, are associated with worse prognosis [2].

The most common metastatic sites of NETs are the lymph nodes, liver and lung. Cutaneous metastases are considered rare. Only 28 articles were accessed, totaling 31 cases, which are summarized in table 1 . There was a slight prevalence in men (16/31), with a mean age of 55 years at the time of diagnosis (ranging from 19 to 82 years). In most cases, the lesions were single or multiple nodules, nonulcerated, painless, of slow growth, ranging from 0.5 to $2.5 \mathrm{~cm}$ in diameter and clinically unspecific like other cutaneous metastasis. The location was most frequently on the cephalic segment (typically on the scalp) and/or trunk. We call attention to two distinct cases: (1) painful spots referred by the patient without visible or palpable cutaneous lesions; (2) single hardened lesion on the eyelid, simulating the primary cutaneous lesion [8-35].

Most of the cases presented with painless lesions, although in some patients the lesions can be painful. In this context, primary painful cutaneous tumors are important differential diagnoses. They can be easily remembered by the acronym LEND AN EGG (leiomyoma, eccrine spiradenoma, neuroma, dermatofibroma, angiolipoma, neurilemmoma, endometrioma, glomus tumor and granular cell tumor) [36].

Prognosis is not good. The 5 -year survival rate is $19 \%$ for patients with metastatic NEC [3]. Despite chemotherapy, an effort should be made for the identification of the primary site, since its resection will increase the disease-free survival and allow appropriate chemotherapy [7].

\section{Conclusion}

Cutaneous metastases of NEC are rare, but it is important to emphasize the relevance of the dermatologist in such cases. Clinical suspicion and histopathology diagnosis permitted the identification of the disease progression, which was a determinant factor for modifying the chemotherapy protocol.

\section{Statement of Ethics}

Our patient gave his written authorization for the publication of his case, and the authors followed all ethical guidelines. 


\section{Case Reports in Dermatology}

Amorim et al.: Cutaneous Metastasis of Neuroendocrine Carcinoma with Unknown Primary Site: Case Report and Review of the Literature

\section{Disclosure Statement}

The authors declare no conflicts of interest.

\section{References}

1 Klimstra DS, Beltran H, Lilenbaum R, Bergsland E: The spectrum of neuroendocrine tumors: histologic classification, unique features and areas of overlap. Am Soc Clin Oncol Educ Book 2015;35:92-103.

2 Araujo NAA, Pantaroto A, Oliveira CT: Tumores neuroendócrinos: revisão de literatura. Perspectivas médicas 2012;23:35-41.

-3 Niwa ABM, Nico MMS: Síndrome carcinóide: relato de caso. An Bras Dermatol 2008;83:549-553.

4 Taal BG, Visser O: Epidemiology of neuroendocrine tumors. Neuroendocrinology 2004;80(suppl 1):3-7.

5 Bell HK, Poston GJ, Vora J, Wilson NJ: Cutaneous manifestations of the malignant carcinoid syndrome. Br J Dermatol 2005;152:71-75.

6 Pavlidis N, Fizazi K: Carcinoma of unknown primary (CUP). Crit Rev Oncol Hematol 2009;69:271-278.

7 Santhanam P, Chandramahanti S, Kroiss A, et al: Nuclear imaging of neuroendocrine tumors with unknown primary: why, when and how? Eur J Nucl Med Mol Imaging 2015;42:1144-1155.

$>8$ Jedrych J, Busam K, Pulitzer K, Pulitzer M: Cutaneous metastases as an initial manifestation of visceral welldifferentiated neuroendocrine tumor: a report of four cases and review of literature. J Cutan Pathol 2014;41:113-122.

-9 Reingold IM, Escovitz WE: Metastatic cutaneous carcinoid: report of a case of functioning malignant bronchial carcinoid. Arch Dermatol 1960;82:971-975.

10 Bean SF, Fusaro RM: An unusual manifestation of the carcinoid syndrome: report of a case. Arch Dermatol 1968;98:268-269.

11 Colin-Jones DG, Copping RM, Gibbs DD, Sharr MM: Malignant Zollinger-Ellison syndrome with gastrincontaining skin metastases. Lancet 1969;1:492-494.

12 Sullivan JL, Packer JT, Bryant M: Primary malignant carcinoid of the testis. Arch Pathol Lab Med 1981;105:515-517.

13 Archer CB, Wells RS, MacDonald DM: Metastatic cutaneous carcinoid. J Am Acad Dermatol 1985;13(2 pt 2):363-366. Rodriguez G, Villamizar R: Carcinoid tumor with skin metastasis. Am J Dermatopathol 1992;14:263-269. Schmidt U, Metz KA, Schrader M, Leder LD: Well-differentiated (oncocytoid) neuroendocrine carcinoma of the larynx with multiple skin metastases: a brief report. J Laryngol Otol 1994;108:272-274.

$\$ 16$ Grunewald B, Viggiano J, Chapman E: Widespread intraabdominal carcinoid tumor presenting as an umbilical metastasis: diagnosis by fine-needle aspiration. Diagn Cytopathol 1996;15:457-458.

17 McCracken GA, Washington CV, Templeton SF: Metastatic cutaneous carcinoid. J Am Acad Dermatol 1996;35:997-998.

18 Ereño C, Lopez JI, Sanchez JM: Atypical carcinoid of larynx: presentation with scalp metastases. J Laryngol Otol 1997;111:89-91.

19 De Argila D, Bureo JC, Márquez FL, Pimentel JJ: Small-cell carcinoma of the lung presenting as a cutaneous metastasis of the lip mimicking a Merkel cell carcinoma. Clin Exp Dermatol 1999;24:170-172.

20 Ottinetti A, Colombo E, Dardano F, et al: Cutaneous metastasis of neuroendocrine carcinoma of the larynx: report of a case. J Cutan Pathol 2003;30:512-515.

21 Zhang Y, Selvaggi SM: Metastatic islet cell carcinoma to the umbilicus: diagnosis by fine-needle aspiration. Diagn Cytopathol 2003;29:91-94.

22 Bell HK, Poston GJ, Vora J, Wilson NJ: Cutaneous manifestations of the malignant carcinoid syndrome. Br J Dermatol 2005;152:71-75.

23 Vidulich KA, Donley SE, Duvic M: Multinodular cutaneous spread in neuroendocrine tumor of the breast: an unusual presentation. Am J Clin Dermatol 2007;8:379-383.

24 Santi R, Massi D, Mazzoni F, Antonuzzo L, Comin CE: Skin metastasis from typical carcinoid tumor of the lung. J Cutan Pathol 2008;35:418-422.

25 Chung WK, Yang JH, Chang SE, et al: A case of cutaneous metastasis of small-cell neuroendocrine carcinoma of the uterine cervix. Am J Dermatopathol 2008;30:636-638.

-26 Lee WJ, Kim CH, Chang SE, et al: Cutaneous metastasis from large-cell neuroendocrine carcinoma of the urinary bladder expressing CK20 and TTF-1. Am J Dermatopathol 2009;31:166-169.

27 Simpson LK, Ostlere LS, Harland C, Gharaie S: Treatment with carbon dioxide laser of painful skin metastases from a laryngeal neuroendocrine carcinoma. Clin Exp Dermatol 2009;34:e873-e875.

28 Blochin E, Stein JA, Wang NS: Atypical carcinoid metastasis to the skin. Am J Dermatopathol 2010;32:735739.

29 Yu R, Wolin E, Fan X: Single subcutaneous nodule as initial presentation of atypical lung carcinoid. World J Oncol 2010;1:204-207. 


\section{Case Reports in \\ Dermatology}

\begin{tabular}{l|l}
\hline Case Rep Dermatol 2015;7:263-274 \\
\hline DOI: $10.1159 / 000440661$ & $\begin{array}{l}\text { (c) 2015 The Author(s). Published by S. Karger AG, Basel } \\
\text { www.karger.com/cde }\end{array}$ \\
\hline
\end{tabular}

Amorim et al.: Cutaneous Metastasis of Neuroendocrine Carcinoma with Unknown Primary Site: Case Report and Review of the Literature

30 Sanii S, Tavangar SM: Cutaneous metastasis of medullary carcinoma as the initial manifestation an otherwise limited malignancy: a case report. Am J Dermatopathol 2011;33:716-718.

-31 Boyd AS, Hayes BB: Metastatic small cell neuroendocrine carcinoma of the breast. J Cutan Pathol 2012;39:1042-1046.

-32 Fluehler C, Quaranta L, di Meo N, Ulessi B, Trevisan G: Cutaneous metastasis of neuroendocrine carcinoma. Indian J Dermatol 2013;58:247.

-33 Yuan C, Keating B, Farricielli LA, Zhang K: Large-cell neuroendocrine carcinoma (LCNEC) without pulmonary symptoms diagnosed in a cutaneous metastasis. Am J Case Rep 2014;15:97-102.

-34 Ishida M, Iwai M, Kagotani A, Iwamoto N, Okabe H: Cutaneous metastasis from pulmonary large cell neuroendocrine carcinoma in the scalp. Int J Clin Exp Pathol 2014;7:2701-2706.

35 Wang SM, Ye M, Ni SM: Multiple scalp metastases from colonic neuroendocrine carcinoma: case report and literature review. BMC Cancer 2014;14:305.

36 Naversen DN, Trask DM, Watson FH, Burket JM: Painful tumors of the skin: 'LEND AN EGG'. J Am Acad Dermatol 1993;28(2 pt 2):298-300. 
Amorim et al.: Cutaneous Metastasis of Neuroendocrine Carcinoma with Unknown

Primary Site: Case Report and Review of the Literature

Table 1. Cases of cutaneous metastasis of NEC found in PubMed

\begin{tabular}{|c|c|c|c|c|}
\hline $\begin{array}{l}\text { First authors [Ref.], } \\
\text { year }\end{array}$ & $\begin{array}{l}\text { Age, } \\
\text { years }\end{array}$ & Gender & Primary site & Lesion type and location \\
\hline Reingold [9], 1960 & 35 & M & Lung & $\begin{array}{l}\text { Subcutaneous nodules; diffusely distributed, } \\
\text { except face, hands and feet }\end{array}$ \\
\hline Bean [10], 1968 & 62 & $\mathrm{M}$ & Unknown & $\begin{array}{l}\text { Multiple nodules in a dome format; scalp and } \\
\text { anterior trunk }\end{array}$ \\
\hline $\begin{array}{l}\text { Colin-Jones [11], } \\
1969\end{array}$ & 73 & $\mathrm{~F}$ & Pancreas & Painless nodules; abdomen and limbs \\
\hline Sullivan [12], 1981 & 19 & $\mathrm{M}$ & Testicles & Nodules; trunk \\
\hline Archer [13], 1985 & 68 & $\mathrm{~F}$ & Lung & $\begin{array}{l}\text { Subcutaneous nodules, cervical region; trunk and } \\
\text { thighs }\end{array}$ \\
\hline $\begin{array}{l}\text { Rodriguez [14], } \\
1992\end{array}$ & 80 & M & Stomach & $\begin{array}{l}\text { Subcutaneous nodules; forehead, posterior cervi- } \\
\text { cal region, trunk and thighs }\end{array}$ \\
\hline Schmidt [15], 1994 & 63 & $\mathrm{~F}$ & Larynx & Painful nodules, diffusely distributed on the body \\
\hline Grunewald [16], 1996 & 62 & $\mathrm{~F}$ & Gastrointestinal tract & Nodule; umbilical scar \\
\hline McCracken [17], 1996 & 67 & $\mathrm{M}$ & Gastrointestinal tract & Hard nodule; left superior eyelid \\
\hline Ereño [18], 1997 & 72 & $\mathrm{~F}$ & Larynx & Hard nodules; scalp \\
\hline De Argila [19], 1999 & 71 & M & Lung & $\begin{array}{l}\text { Single pinkish erythematous nodule with superfi- } \\
\text { cial erosion; face }\end{array}$ \\
\hline Ottinetti [20], 2003 & 61 & $\mathrm{M}$ & Larynx & $\begin{array}{l}\text { Hard erythematous violaceous nonulcerated } \\
\text { nodules; trunk }\end{array}$ \\
\hline Zhang [21], 2003 & 34 & $\mathrm{~F}$ & Pancreas & Hard nodule; periumbilical \\
\hline Bell [22], 2005 & 69 & $\mathrm{M}$ & Rectum & Multiple subcutaneous nodules \\
\hline Vidulich [23], 2007 & 76 & $\mathrm{~F}$ & Breast & $\begin{array}{l}\text { Nodules in annular disposition, in contiguity to a } \\
\text { breast tumoral mass }\end{array}$ \\
\hline Santi [24], 2008 & 60 & $\mathrm{M}$ & Lung & $\begin{array}{l}\text { Erythematous violaceous nodule, with rapid } \\
\text { growth; dorsum }\end{array}$ \\
\hline Chung [25], 2008 & 31 & $\mathrm{~F}$ & Uterus & Two erythematous purpuric nodules; scalp \\
\hline Lee [26], 2009 & 20 & $\mathrm{M}$ & Bladder & $\begin{array}{l}\text { Single erythematous dome format nodule with } \\
\text { central ulceration; scalp }\end{array}$ \\
\hline Simpson [27], 2009 & 82 & $\mathrm{M}$ & Larynx & $\begin{array}{l}\text { Painful erythematous papules and nodules; head, } \\
\text { neck and trunk }\end{array}$ \\
\hline Blochin [28], 2010 & 55 & $\mathrm{~F}$ & Lung & $\begin{array}{l}\text { Painful points, without visible erythema or palpa- } \\
\text { ble nodule; scalp }\end{array}$ \\
\hline Yu [29], 2010 & 50 & $\mathrm{~F}$ & Lung & Single subcutaneous nodule; right axilla \\
\hline Sanii [30], 2011 & 79 & $\mathrm{~F}$ & Thyroid & $\begin{array}{l}\text { Multiple erythematous painful nodules and } \\
\text { plaques; right forearm, abdomen and back }\end{array}$ \\
\hline Boyd [31], 2012 & 50 & $\mathrm{~F}$ & Breast & $\begin{array}{l}\text { Erythematous papules and nodules over the skin } \\
\text { of the reconstructed left breast }\end{array}$ \\
\hline Fluehler [32], 2013 & 65 & $\mathrm{M}$ & Gastrointestinal tract & $\begin{array}{l}\text { Single erythematous nodular lesion with } \\
\text { telangiectasias; face }\end{array}$ \\
\hline Yuan [33], 2014 & 60 & $\mathrm{~F}$ & Lung & $\begin{array}{l}\text { Single erythematous nodular lesion on the } \\
\text { breast }\end{array}$ \\
\hline Ishida [34], 2014 & 55 & $\mathrm{M}$ & Lung & Single subcutaneous nodule; scalp \\
\hline Wang [35], 2014 & 62 & $\mathrm{M}$ & Gastrointestinal tract & Multiple subcutaneous nodules; scalp \\
\hline \multirow[t]{4}{*}{ Jedrych [8], 2014} & 50 & $\mathrm{~F}$ & Lung & $\begin{array}{l}\text { Single painless nodule, nonulcerated, slow } \\
\text { progressive growth; scalp }\end{array}$ \\
\hline & 74 & M & Lung & $\begin{array}{l}\text { Single painless nodule, nonulcerated, slow } \\
\text { progressive growth; scalp }\end{array}$ \\
\hline & $\overline{67}$ & $\mathrm{~F}$ & Pancreas & $\begin{array}{l}\text { Single painless nodule, nonulcerated, slow } \\
\text { progressive growth; scalp }\end{array}$ \\
\hline & $\overline{67}$ & $\mathrm{~F}$ & $\begin{array}{l}\text { Gastrointestinal } \\
\text { tract }\end{array}$ & $\begin{array}{l}\text { Single painless nodule, nonulcerated, slow } \\
\text { progressive growth; dorsum }\end{array}$ \\
\hline
\end{tabular}




\section{Case Reports in Dermatology}

Case Rep Dermatol 2015;7:263-274

Amorim et al.: Cutaneous Metastasis of Neuroendocrine Carcinoma with Unknown Primary Site: Case Report and Review of the Literature

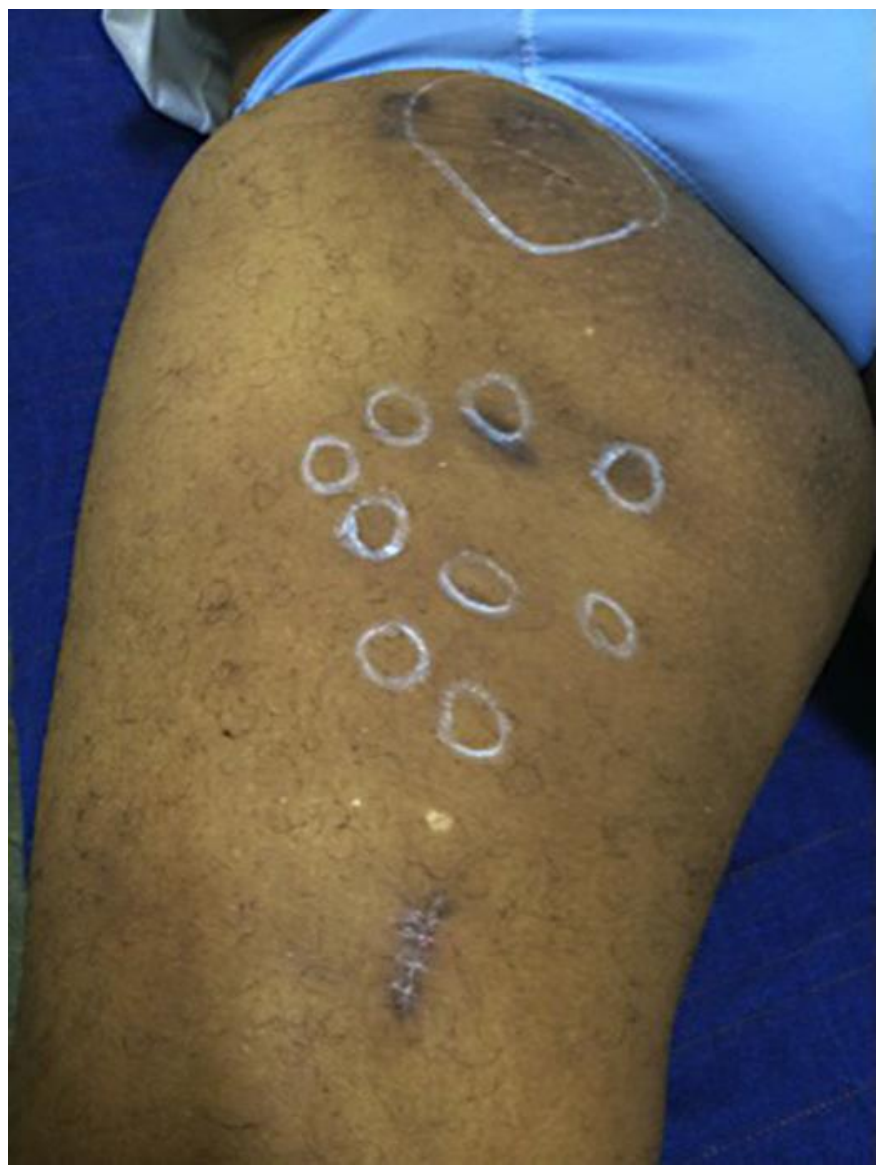

Fig. 1. Marking of the site of the inguinal lymph node previously excised and, in the smaller round markings, the nodular subcutaneous lesions on the right thigh. 


\section{Case Reports in Dermatology}

Case Rep Dermatol 2015;7:263-274

DOI: $10.1159 / 0004061$

(c) www.karger.com/cde

Amorim et al.: Cutaneous Metastasis of Neuroendocrine Carcinoma with Unknown Primary Site: Case Report and Review of the Literature

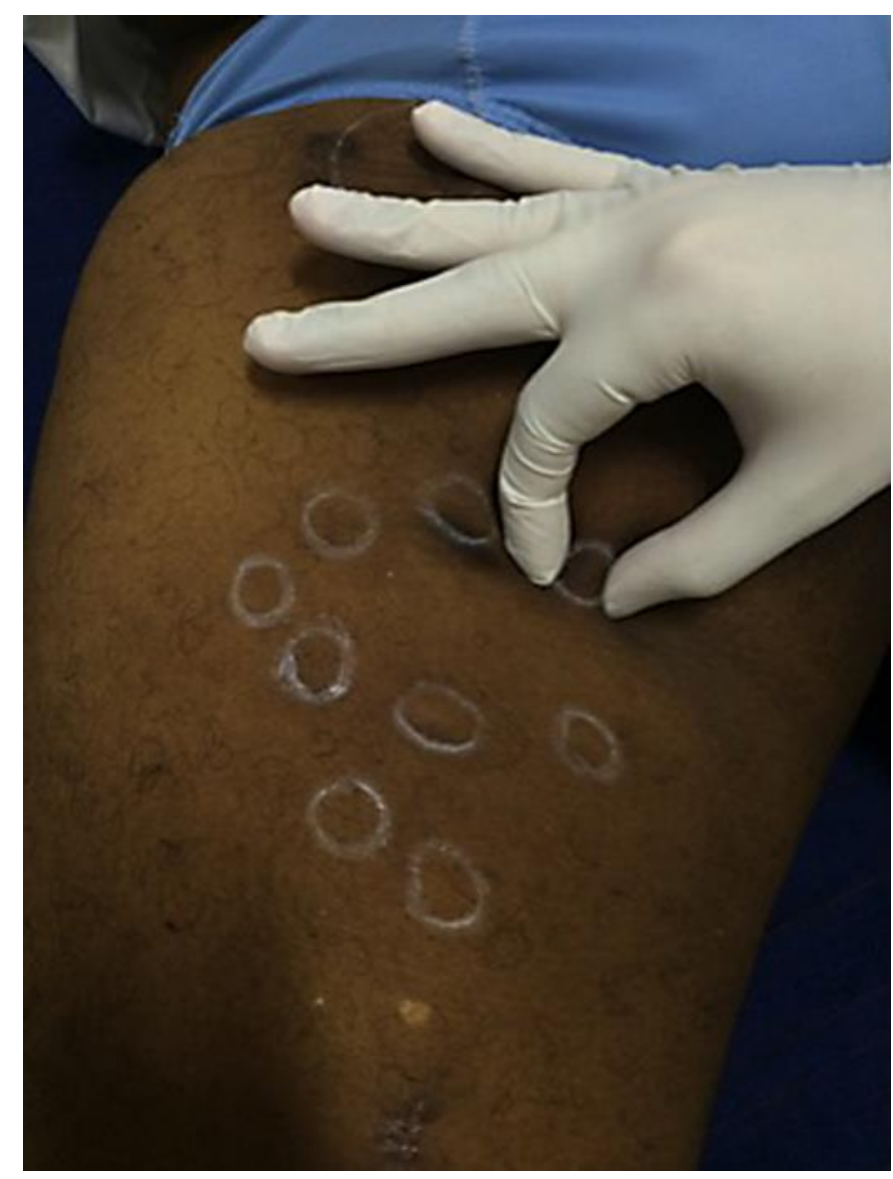

Fig. 2. Palpation of the nodular subcutaneous lesion on the right thigh (in detail). 


\section{Case Reports in Dermatology}

Case Rep Dermatol 2015;7:263-274

DOI: $10.1159 / 000440661$

(c) Author(s). Published by S. Karger AG, Basel

Amorim et al: Cutaneous Metastasis of Neuroendocrine Carcinoma with Unknown Primary Site: Case Report and Review of the Literature

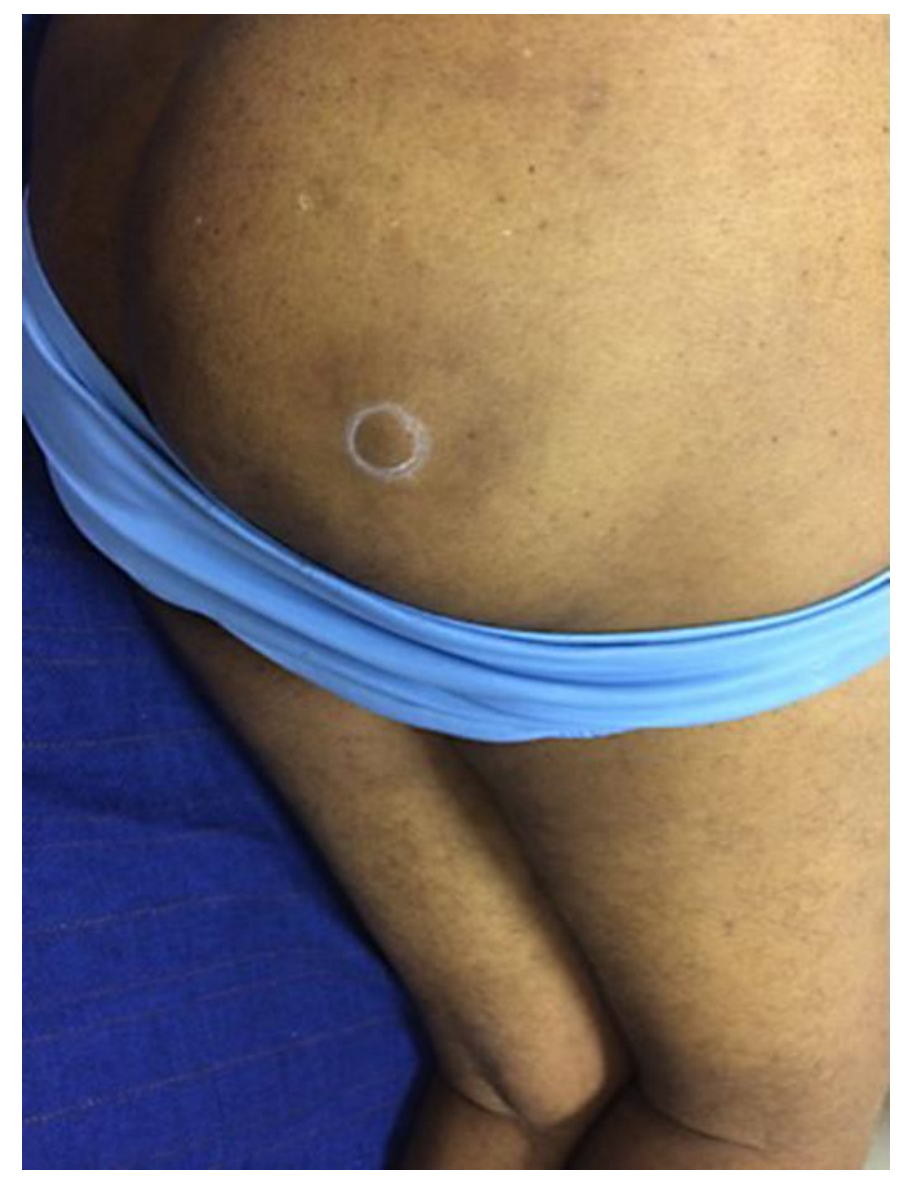

Fig. 3. Nodular isolated lesion on the right buttock. 


\section{Case Reports in Dermatology}

\begin{tabular}{l|l}
\hline Case Rep Dermatol 2015;7:263-274 \\
\hline DOI: 10.1159/000440661 & $\begin{array}{l}\text { (c) 2015 The Author(s). Published by S. Karger AG, Basel } \\
\text { www.karger.com/cde }\end{array}$ \\
\hline
\end{tabular}

Amorim et al: Cutaneous Metastasis of Neuroendocrine Carcinoma with Unknown Primary Site: Case Report and Review of the Literature

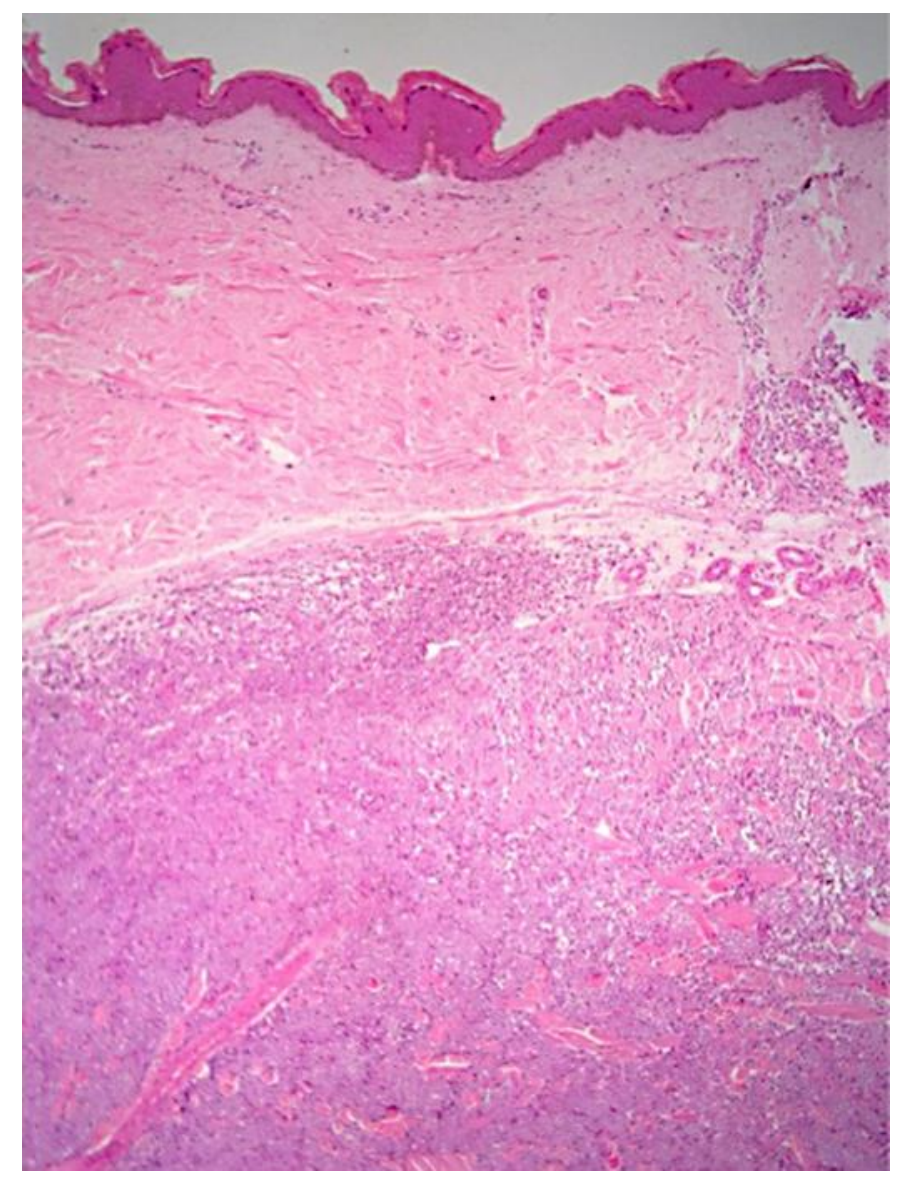

Fig. 4. Nodular lesion on the dermis and hypodermis. HE. $\times 40$.

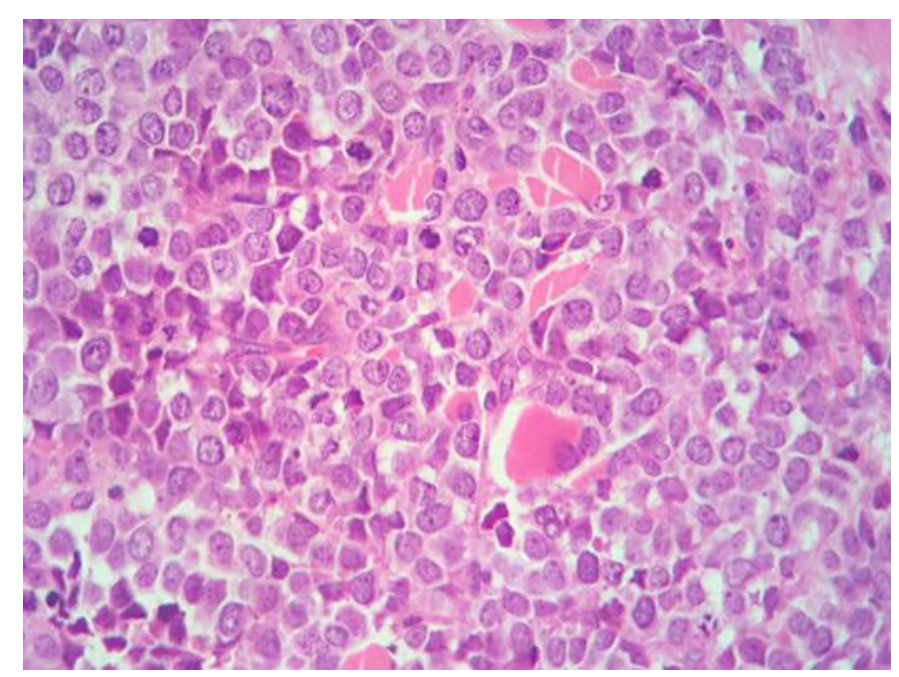

Fig. 5. Monomorphic proliferation of cells with poorly defined cytoplasmic borders and round nucleus with uniformly distributed fine granular chromatin. HE. $\times 400$. 


\section{Case Reports in Dermatology}

Case Rep Dermatol 2015;7:263-274

Amorim et al: Cutaneous Metastasis of Neuroendocrine Carcinoma with Unknown Primary Site: Case Report and Review of the Literature

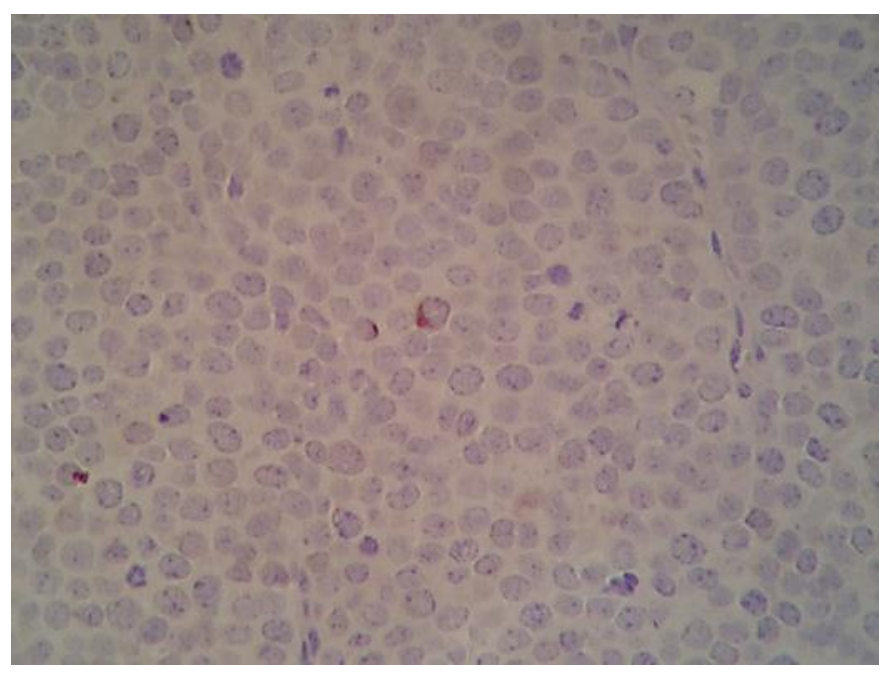

Fig. 6. Focal positivity in dot for CK20. CK20. $\times 400$.

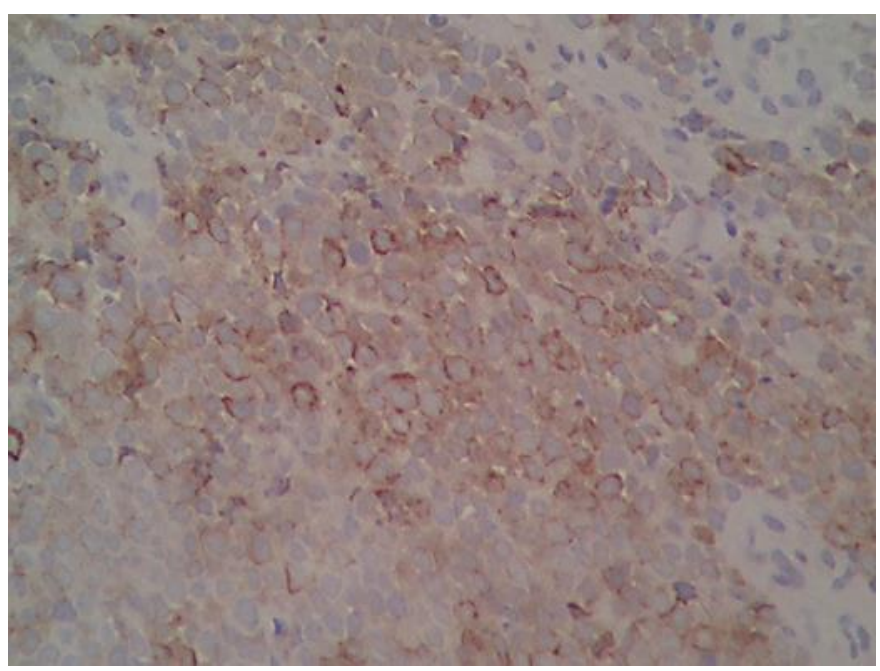

Fig. 7. Positivity for Chromogranin. Chromogranin. $\times 400$. 


\section{Case Reports in Dermatology}

Case Rep Dermatol 2015;7:263-274

DOI: $10.1159 / 00040601$

(c) 2015 www.karger.com/cde

Amorim et al.: Cutaneous Metastasis of Neuroendocrine Carcinoma with Unknown Primary Site: Case Report and Review of the Literature

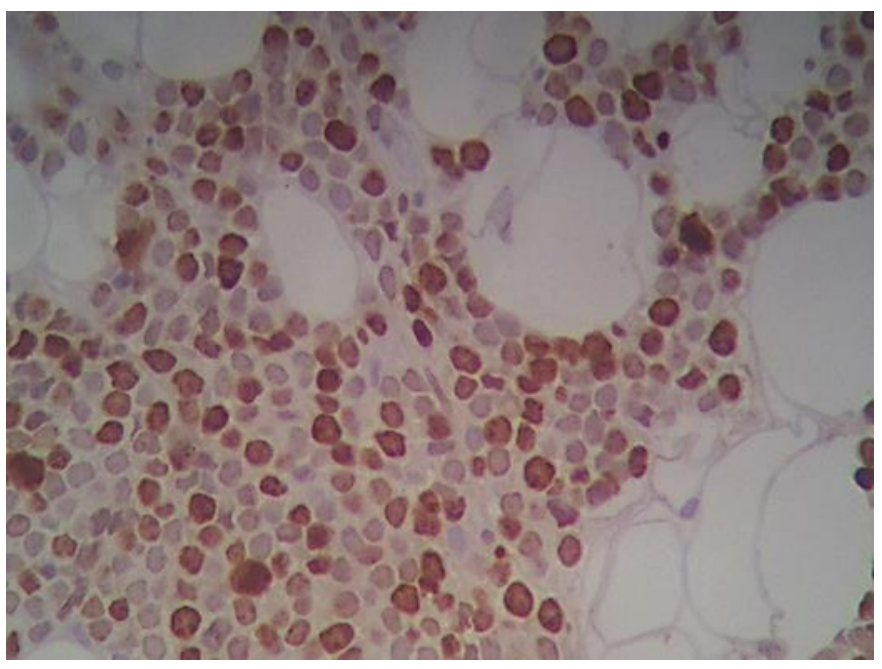

Fig. 8. Positivity for Ki67 (MIB-1) of about $60 \%$. Ki67. $\times 400$. 